\title{
Immune Effects of Transtuzumab in HER2 Positive Breast Cancer
}

\author{
ANCA ZGURA ${ }^{1}$, LAURENTIA GALES ${ }^{1}$, BOGDAN HAINEAL A ${ }^{1}$, ELVIRA BRATILA ${ }^{1}$, CLAUDIA MEHEDINTU ${ }^{1 *}$, \\ RAMONA ILEANA BARAC ${ }^{1}$, COSTIN BERCEANU ${ }^{2}$, CRISTINA VERONICA ANDREESCU ${ }^{1}$, LACRAMIOARA AURELIA BRINDUSE ${ }^{1}$, \\ ALEC IONESCU ${ }^{1}$, RODICA ANGHEL ${ }^{1}$ \\ ${ }^{1}$ The University of Medicine and Pharmacy Carol Davila, 8 Eroii Sanitari Blvd., 050474, Bucharest, Romania \\ 2The University of Medicine and Pharmacy, 2 Petru Rares Str., 200349, Craiova, Romania
}

\begin{abstract}
The immune system could mediate the antitumor activity of several anticancer treatments. Several chemotherapy compounds, including anthracyclines and oxaliplatin, induce immunogenic cell death that in turn activates the antitumor immune response. Trastuzumab induces antibody-dependant cell-mediated cytotoxicity. On the basis of this background, immune markers have recently been the focus of intense translational research to predict and monitor the efficacy of treatments. Gene expression arrays and immunohistochemistry have assessed immune activation and infiltration by macrophages, natural killer, and $T$ and $B$ lymphocytes. In this paper we present the results of a study that included 22 patients diagnosed with Her2 positive breast cancer undergoing treatment with Transtuzumab.
\end{abstract}

Keywords: chemotherapy, trastuzumab, cytotoxicity, $T$ and $B$ lymphocytes

Breast cancer is a multifactorial disease in which the key mechanisms of cellular function are implicated, involving molecules of different biochemical classes, functions and types: hormones, growth factors, receptors, signalling pathways, proteases, chromosomal genes, and specific molecules of ribonucleic acids [1-2]. Each of these factors represents a direct therapeutic target, describing a new era in the cancer therapy-molecular biological therapy [3].

The human epidermal growth factor receptor (EGFR) family comprises four transmembrane receptors, which are involved in the signal transduction pathways regulating cell growth and differentiation: EGFR/HER1, c-erbB2/HER2, HER3, and HER4 [2,3]. Breast cancers overexpressing the human epidermal growth factor receptors, HER1 (EGFR/ c-erbB-1) or HER2 (neu-c-erbB-2), have been associated with disease progression, survival, stage and treatment response [4]. HER2 expression in breast cancer tissue is indicative of an aggressive pathology and it is considered a marker of poor prognosis.

The development of trastuzumab and lapatinib has improved the way for women with HER2-positive disease [5-6].

The targeted therapy of Trastuzumab represents the standard treatment for breast cancer patients with HER2 positive [7]. There has been increasing evidence that the immune system plays a significant role in the therapeutic effects of HER2-targeted therapy [8].

\section{Experimental part}

The prospective study was conducted on a group of 22 women treated in The Institute of Oncology Bucharest. The study group comprised breast cancer patients with HER 2 positive.

The HER2 overexpression was assessed using the immunohistochemical method in postradical mastectomy or in samples obtained by thick needle biopsy. The second part of the study was the test blood with flow cytometry.

The inclusion criteria for the treatment with Trastuzumab were: LVEF $>50 \%$ and medical history without major pathologies.

Patients characteristics are shown in table 1.
Table 1

CHARACTERISTICS OF THE STUDIED LOT

\begin{tabular}{|l|l|}
\hline Characteristics & Cases (n, range, \%) \\
\hline Median age, years (range) & $\mathbf{5 9 . 6 4}$ years \\
\hline Depth & \\
\hline T1 $(\leq 2 \mathrm{~cm})$ & $4(18.1 \%)$ \\
\hline T2 $(>2$ and $\leq 5 \mathrm{~cm})$ & $14(63.8 \%)$ \\
\hline T3 $(>5 \mathrm{~cm})$ & $4(18.1 \%)$ \\
\hline Number of metastatic lymph nodes & \\
\hline 0 & $4(18.1 \%)$ \\
\hline 1 & $1(0.22 \%)$ \\
\hline $2-5$ & $8(36.36 \%)$ \\
\hline$>5$ & $9(49.90 \%)$ \\
\hline Cut-off value of CD4/CD8 ratio & 1.69 \\
\hline ER & \\
\hline Negative (0-1+) & $\mathbf{2 ( 9 . 0 9 \% )}$ \\
\hline Overexpressed (2-3+) & $\mathbf{2 0}(90.9 \%)$ \\
\hline PR & \\
\hline Negative (0-1+) & $4(18.18 \%)$ \\
\hline Overexpressed (2-3+) & $18(81.81 \%)$ \\
\hline Ki67 & $\mathbf{2 2 . 5 9 \%}$ \\
\hline Treatment regimen & \\
\hline Surgery only & 0 \\
\hline Surgery plus postoperative C & $\mathbf{2 2}(100 \%)$ \\
\hline Surgery plus postoperative HT & $13(59.09 \%)$ \\
\hline Surgery plus postoperative RT & $9(40.90 \%)$ \\
\hline Abrevations: $R-$ radiotherapy; C- chemotherapy;
\end{tabular}

Abbreviations: $R$ - radiotherapy; $C$ - chemotherapy;

HT- hormonal therapy.

The mean age of the patients studied was 59.64 years, the minimum being 31 years and the maximum 82 years. The average follow-up was 27.18 months.

The low correlation test $(0.0024)$ demonstrates a correlation between the higher patient age and the positivity for HER-2.

To evaluate the immune response, we evaluated the percentage of T-lymphocytes in the peripheral blood for 19 patients diagnosed with Her2 positive breast cancer undergoing treatment with Transtuzumab.

The standard treatment for breast cancer patients includes surgery, chemotherapy, radiotherapy and hormonal therapy. This treatment was administered according to the clinical and pathological characteristics of the ESMO and NCCN guides [9-10]. 


\begin{tabular}{|c|c|c|c|c|c|}
\hline \multicolumn{6}{|c|}{ Descriptive Statistics $^{2}$} \\
\hline & $\mathrm{N}$ & Minimum & Maximum & Mean & Std. Deviation \\
\hline $\begin{array}{l}\text { Months after } \\
\text { diagnosis }\end{array}$ & 22 & 2 & 54 & 27.18 & 17.840 \\
\hline Age & 22 & 31 & 82 & 59.64 & 15.268 \\
\hline $\begin{array}{l}\text { ValidN } \\
\text { (listwise) }\end{array}$ & 22 & & & & \\
\hline
\end{tabular}

Table 2

DISTRIBUTION OF HER-2 / NEU POSITIVE PATIENTS BY AGE

Table 3

STATISTICAL CORRELATION BETWEEN HER-2 / NEU POSITIVE AND AGE

\begin{tabular}{|c|c|c|c|c|c|c|c|c|c|c|}
\hline \multicolumn{11}{|c|}{ Independent Samples Test } \\
\hline & & \multicolumn{2}{|c|}{$\begin{array}{l}\text { Levene's Test for } \\
\text { Equality of } \\
\text { Variances }\end{array}$} & \multicolumn{7}{|c|}{ t-test for Equality of Means } \\
\hline & & \multirow[t]{2}{*}{$F$} & \multirow[t]{2}{*}{ Sig. } & \multirow[t]{2}{*}{$\mathrm{t}$} & \multirow[t]{2}{*}{ df } & \multirow[t]{2}{*}{$\begin{array}{l}\text { Sig. } \\
(2- \\
\text { tailed) }\end{array}$} & \multirow[t]{2}{*}{$\begin{array}{l}\text { Mean } \\
\text { Difference }\end{array}$} & \multirow[t]{2}{*}{$\begin{array}{l}\text { Std. Error } \\
\text { Difference }\end{array}$} & \multicolumn{2}{|c|}{$\begin{array}{l}95 \% \text { Confidence } \\
\text { Interval of the } \\
\text { Difference }\end{array}$} \\
\hline & & & & & & & & & Lower & Upper \\
\hline \multirow[t]{2}{*}{ Age } & $\begin{array}{l}\text { Equal } \\
\text { variances } \\
\text { assumed }\end{array}$ & 1.029 & .315 & 2.327 & 54 & .024 & 8.901 & 3.824 & 1.234 & 16.569 \\
\hline & $\begin{array}{l}\text { Equal } \\
\text { variances not } \\
\text { assumed }\end{array}$ & & & 2.251 & 39.973 & .030 & 8.901 & 3.954 & .909 & 16.893 \\
\hline
\end{tabular}

The 22 patients included in the study underwent adjuvant cytostatic and neoadjuvant chemotherapy using the CMF chemotherapy followed by Docetaxel $100 \mathrm{mg} / \mathrm{m}^{2}$ or EC chemotherapy followed by Docetaxel. Patients who had positive hormone receptors followed hormone treatment (Tamoxifen or Anastrozole). For patients confirmed with Her2 in the IHC or $\mathrm{ClSH}$, the treatment with Trastuzumab was started.
In order to better understand the effects of Transtuzumab on the adaptive immune system, peripheral blood samples were collected from a group of 19 patients who had positive HER-2 / neu in the second part of the study.

The mean CD3 + T score for Her- 2 / neu positive patients was $52.25 \%$.

The mean CD4 + T score for Her-2/ neu positive patients was $27.69 \%$.

\begin{tabular}{|c|c|c|c|c|c|}
\hline \multicolumn{2}{|c|}{ HER } & $N$ & Mean & $\begin{array}{c}\text { Std. } \\
\text { Deviation }\end{array}$ & $\begin{array}{c}\text { Std. Error } \\
\text { Mean }\end{array}$ \\
\hline \multirow{2}{*}{ CD3.1 } & Positive & 19 & 52.2553 & 10.8316 & 2.4850 \\
\cline { 2 - 6 } & Negative & 31 & 53.0790 & 10.1545 & 1.8238 \\
\hline \multirow{2}{*}{ CD4.1 } & Positive & 19 & 27.6963 & 5.8994 & 1.3534 \\
\cline { 2 - 6 } & Negative & 31 & 29.1235 & 7.6046 & 1.3658 \\
\hline \multirow{2}{*}{ CD8.1 } & Positive & 19 & 19.7905 & 5.9778 & 1.3714 \\
\cline { 2 - 6 } & Negative & 31 & 19.8223 & 6.5913 & 1.1838 \\
\hline \multirow{2}{*}{ DP.1 } & Positive & 19 & 1.5316 & 1.5367 & 0.3525 \\
\cline { 2 - 6 } & Negative & 31 & 1.1826 & 1.6467 & 0.2958 \\
\hline \multirow{2}{*}{ DN.1 } & Positive & 19 & 3.2421 & 2.1602 & 0.4956 \\
\cline { 2 - 6 } & Negative & 31 & 2.6252 & 1.5231 & 0.2736 \\
\hline \multirow{2}{*}{ CD4_CD8.1 } & Positive & 19 & 1.4916 & 0.4481 & 0.1028 \\
\cline { 2 - 6 } & Negative & 31 & 1.6897 & 0.9435 & 0.1695 \\
\hline
\end{tabular}

Table 4

MEAN T LYMPHOCYTES ACCORDING TO HER-2 / NEU 
The mean CD8 + T score for Her-2/ neu positive patients was $19.79 \%$.

The average CD4 + / CD8 + ratio was 1.69 .

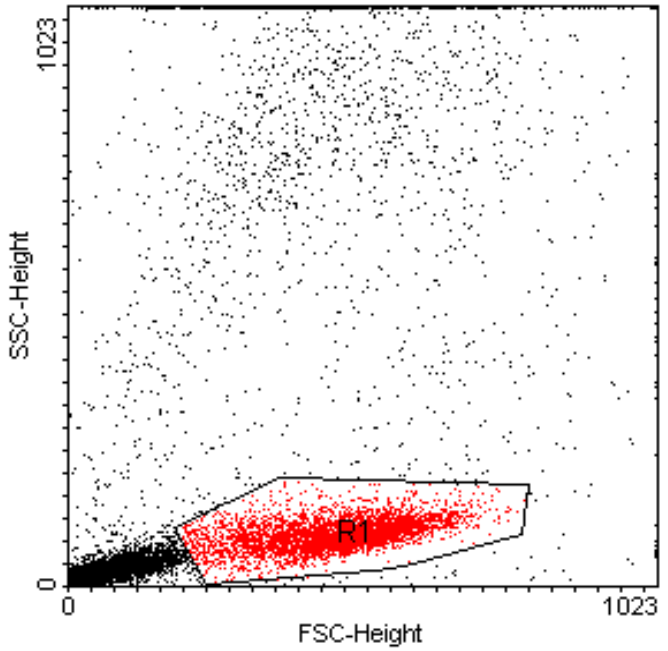

Fig. 1 Flow cytometric evaluation of FCS

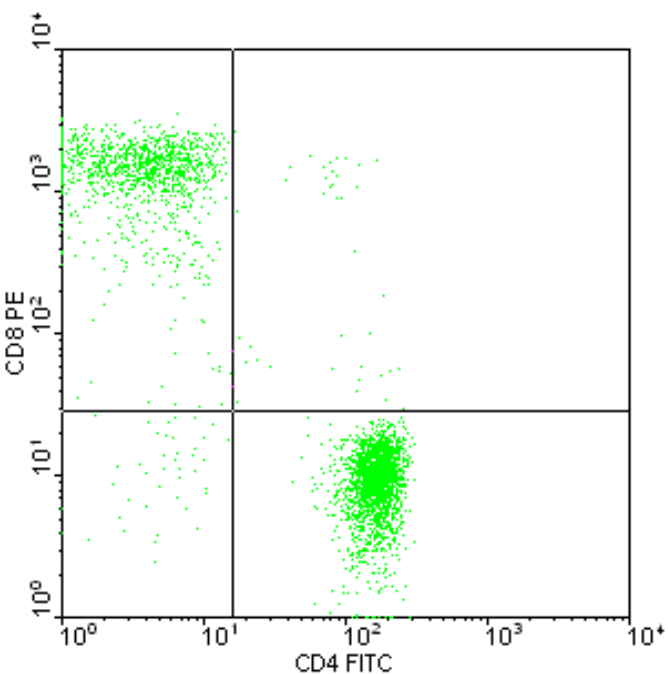

Fig. 2 Flow cytometric evaluation of CD3-PerCP

The results were presented graphically in the form of dot plot, each point representing an event / cell:

-Figure 1: FSC (cell size vs. SSC (granularity / cell complexity; R1 = lymphocyte population;

-Figure 2: CD3-PerCP (anti-CD3 antibody-associated fluorescence intensity) vs SSC; R2 includes the T lymphocyte population (CD3 +);

-Figure 3: CD4-FITC (anti-CD4 antibody-associated fluorescence intensity) vs. CD8-PE (anti-CD8 antibodyassociated fluorescence intensity).

Of the total of patients who had positive HER 2 positive, only 9 received treatment with Transtuzumab at the time of evaluation.

The mean CD3 T lymphocyte count was 43.88 .

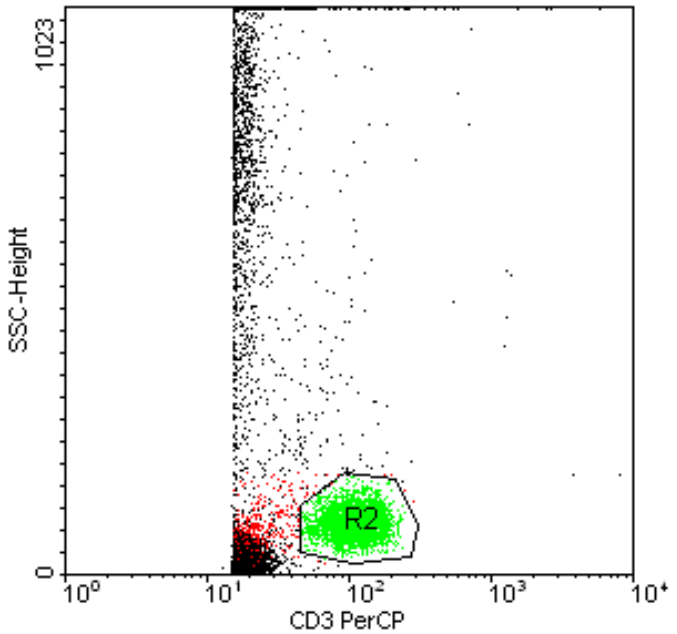

Fig. 3 Flow cytometric evaluation of CD4-FITC vs CD8-PE

The mean CD4 T lymphocyte score of 23.78 and the mean T lymphocyte CD8 of 16.72 .

The mean CD4 / CD8 ratio was 1.48 .

\section{Results and discussions}

In practice, it was observed that the breast cancer patients who are included in the same prognostic group in relation to known prognostic factors (tumor invasive nodes, tumor grading, tumor histology, presence or absence of hormone receptors, KI67, presence or absence of HER2), who underwent the same treatment, have different later developments. This leads to the conclusion that there are a number of other parameters that influence the evolution [11].

HER2 is one of the most studied targets for active immunotherapy. The therapeutic efficacy of Trastuzumab involves the activation of the immune system.

In general, the lowering of the immunoreactive threshold in the neoplastic patient is reflected in the numerical balance of lymphoid cells in the peripheral circulation, that shows deviations from the normal percentages of different cellular sets and subsets, in particular the total $T$ lymphocytes $(\mathrm{CD} 3+)$, the T helper lymphocytes helper CD4 +) and the cytolytic T lymphocytes and suppressor $(C D 8+)$ [9]. Therefore, the determination of the proportions of $C D 3+, C D 4+$ and $C D 8+$ cells is useful in the process of monitoring, by keeping under observation patients with immune status afflicted by cancer, the values of the parameters being obtained and correlated with either the immunodepressive status of the tumor, the extent of its expansion, and the consistency of the immunoreactive means of the body, or with the immunological status resulting from the application of the immunosuppressive treatments (chemotherapy, radiotherapy or immunotherapy) [12].

Age-dependent progressive deterioration of the immune response is referred to as immunosenescence. In our study we observed a significant correlation between

\begin{tabular}{|l|c|c|c|c|c|c|}
\hline & $\mathrm{N}$ & Range & Minimum & Maximum & Mean & Std. Deviation \\
\hline CD3 (\%) & 9 & 32.97 & 22.99 & 55.96 & 43.9856 & 11.24280 \\
\hline CD4 (\%) & 9 & 20.26 & 10.84 & 31.10 & 23.7844 & 7.46628 \\
\hline CD8 (\%) & 9 & 15.67 & 8.85 & 24.52 & 16.7333 & 5.19339 \\
\hline CD4/CD8 & 9 & 1.721059 & 0.950762 & 2.671821 & 1.480460 & 0.521595 \\
\hline $\begin{array}{l}\text { Valid N } \\
\text { (listwise) }\end{array}$ & 9 & & & & & \\
\hline
\end{tabular}

Table 5

MEAN T LYMPHOCYTE FOR PATIENTS UNDERGOING TREATMENT WITH TRANSTUZUMAB 
overexpression of HER2 positive and age, the mean age at diagnosis for the patients with HER2 positive being significantly higher.

Previous studies have shown that the CD4 / CD8 T cell response reflects the status of the immune system and can independently predict all-cause mortality [13-17]. Shah et al. [18] in their study reported that the low ratio of CD4 / CD8 was significantly associated with the worse prognosis of patients with cervical carcinoma, and in the study of Chang-J uan Tao et al. in 2016, it was shown that the higher CD4 / CD8 ratio ( $\mathrm{e}^{\mathrm{TM}}$ 1.77) was associated with the free disease entry.

Patients treated with Docetaxel and Transtuzmab experienced a decrease in the percentage of CD4 + T lymphocytes and an increase in the percentage of CD8 + T lymphocytes, while the Transtuzumab and hormone treated patients had a mean value for CD4 + Tlymphocytes of 23.78 for CD8 +16.73 over time, while the patients who were only on hormone therapy had the mean CD4 + cell count of $28.17 \%$ and CD8 + 20.67 without showing any variations in the values in the successive evaluations.

Recent studies have shown that the therapeutic effect of trastuzumab depends on the acquired and adaptive mechanisms, mediated by immunity. For example, a combination therapy that inhibits the PI3K / AKT pathway for resistance to trastuzumab increases the intratumoral infiltration of $T$ cells, thereby expanding the anti-tumor effect and immune response mediated by CD8 $+\mathrm{T}$ cell, thus enhancing the therapeutic effects of the anti-HER2 antibody [19-20].

Although it is considered that chemotherapy with Transtuzumab treatment has immunosuppressive effects, it has been shown that it also has immunomodulatory effects.

\section{Conclusions}

Recently it has been found that the immune system plays a critical role in the initiation, progression of the tumor and/or response to treatments. The manipulation/targeting of the inhibitory immune molecules has already revolutionized the outcome of many cancers and is now being investigated for the treatment of breast cancer.

Patients undergoing treatment with Docetaxel and Transtuzmab showed a decrease in the percentage of CD4 + T lymphocytes and an increase in the percentage of CD8 + T lymphocytes, while patients treated with Transtuzumab and hormone therapy had a mean value for CD4 + T lymphocytes of 23.78 for CD8 + 16.73 .
It will be very important to note the interaction between the immune system and the new targeted therapies (Lapatinb, Pertuzumab) which may be different from that of Transtuzumab.

\section{References}

1.GREEN S, WALTER P, KUMAR V, KRUST A, BORNERT JM, ET AL. Nature 1986 320:1349.

2.GREENE GL, GILNA P, WATERFIELD M, BAKER A, HORT Y, ET AL.: Science 1986 231:11504.

3.OSBORNE CK. Breast Cancer Res Treat 1998 51:227-38.

4.FLOURIOT G, BRAND H, DENGER S, METIVIER R, KOS M, ET AL.: Embo J 2000 19:4688-700.

5.MUKOHARA T. Cancer Sci 2011;102:1-8

6.J ONES KL, BUZDAR AU. Lancet Oncol 2009;10:1179-87

7.BIANCHINI G, GIANNI L. Lancet Oncol 2014;15:e58-68.

8.DENNIS J. SLAMON, G. M. C., STEVEN G. WONG, WENDY J. LEVIN, AXEL ULLRICH, WILLIAM L. MCGUIRE. Science, 177-183 (1987).

9.NATIONAL COMPREHENSIVE CANCER NETWORK GUIDELINES VERSION 3.2017, BREAST CANCER, HTTPS://WWW.NCCN.ORG/ PROFESSIONALS/PHYSICIAN_GLS/PDF/BREAST-SCREENING.PDF 10.E. SENKUS, S. KYRIAKIDES, S. OHNO, F. PENAULT-LLORCA, P. POORTMANS, E. RUTGERS, S. ZACKRISSON \& F. CARDOSO, Annals of Oncology 26 (Supplement 5): v8-v30, 2015; http://annonc. oxfordjournals.org/ content/26/suppl_5/v8.full.pdf+html;

11.MEHEDINTU, C., BRATILA, E., BERCEANU, C., CIRSTOIU, M., BARAC, R.I., et. al., Rev. Chim.(Bucharest), 69, no. 11, 2018, p.4033-4037

12.XIE, D. W. ET AL. Journal of the National Cancer Institute 92, 412$417(2000)$.

13.LIU F, LANG R, ZHAO J, ET AL. Breast Cancer Res Treat 2011; 130(2): 645-655.

14.MOZAFFARI F, LINDEMALM C, CHOUDHURY A, GRANSTAMBJ ORNEKLETT H, LEKANDER M, NILSSON B, ET AL. Cancer Immunol Immunother. 2009; 58(1):111-20]

15.MARSIGLIANTE S, BISCOZZO L, MARRA A, NICOLARDI G, LEO G, LOBREGLIO GB, ET AL. Cancer Lett 1999;139:33-41]

16.MENARD S, TOMASIC G, CASALINI P, BALSARI A, PILOTTI S, CASCINELLI N, ET AL. Clin Cancer Res 1997;3:817-9.

17.ZGURA, A., GALES, L., BRATILA, E., MEHEDINTU, C., HAINEALA, B.,et. al., Rev. Chim.(Bucharest), 70, no. 5, 2019, p. 1649

18.SHAH W, YAN X, JING L, ZHOU Y, CHEN H, WANG Y. Cell Mol Immunol. 2011;8:59-66

19.MAHMOUD S, LEE A, ELLISI, GREEN AR. Oncoimmunology 2012;1:12

20.ZGURA, A., GALES, L., HAINEAL,A. B., BRATILA, E., MEHEDINTU, C., et. al., Rev. Chim. (Bucharest), 70, no. 7, 2019, p. 2362

Manuscript received: 15.02 .2019 